\title{
Animal Enterprise Terrorism Act becomes law
}

On 27 November 2006, President Bush signed S. 3880, the "Animal Enterprise Terrorism Act," into law ${ }^{1}$. The new law (Public Law No. 109-374), which broadens the Animal Enterprise Protection Act of 1992, will make it easier for the Department of Justice to apprehend, prosecute, and convict animal rights extremists. Specifically, the Act, which was sponsored by Sen. James M. Inhofe (R-OK), does the following:

- "Amends the federal criminal code to revise criminal prohibitions against damaging or interfering with the operations of an animal enterprise to include intentional damage or loss to any real or personal property and intentional threats of death or serious bodily injury against individuals (or their family members, spouses, or intimate partners) who are involved with animal enterprises;

- "Expands such crime to include conspiracies and attempts;

- "Revises and increases monetary and criminal penalties for such crime;

- "Modifies the definition of 'animal enterprise' to include: (1) an enterprise that uses or sells animals or animal products for profit for educational purposes; and (2) an animal shelter, pet store, breeder, or furrier; and

- "Provides that expressive conduct (including picketing or other peaceful demonstration) protected by the First Amendment is not prohibited by this Act $^{2}$."

Under the new law, violators will be punished based on an escalating scale. Minor offenses may result in a fine or a prison term of less than one year. Offenses resulting in the death of another individual will be punishable by life imprisonment.

1. President Signs S. 435, S. 819 , S. 1131, S. 2464 and S. 3880. The White House (27 November 2006). http://www.whitehouse.gov/news/ releases/2006/11/20061127-1.html.

2. S. 3880 . 'Animal Enterprise Terrorism Act'. (28 September 2006).

\section{APHIS forms available online}

In a recent development that will help United States Department of Agriculture(USDA-) registered facilities keep records of their acquisition, disposition, and transportation of dogs, cats and other animals, the Animal and Plant Health Inspection Service (APHIS) is now making the following forms available online:

- APHIS Form 7005: Record of Acquisition and Dogs and Cats on Hand

- APHIS Form 7006: Record of Disposition of Dogs and Cats

- APHIS Form 7006A: Continuation Sheet for Record of Disposition of Dogs and Cats

- APHIS Form 7020: Record of Acquisition, Disposition or Transport of Animals (Other than Dogs and Cats)

Failure to maintain these records, which are required by law (7 USC 2131-2156; 9 CFR, Subchapter A, Parts 1, 2 and 3), can result in a suspension or revocation of license and/or imprisonment for not more than 1 year, or a fine of not more than $\$ 1,000$, or both. 